\title{
New Procedures in the Museums: The Communication Through Immersive Technologies
}

\author{
Filomena Izzo $^{1}$, Domenico Graziano ${ }^{1,2}$, Mario Mustilli ${ }^{1,3}$ \\ ${ }^{1}$ Department of Economics, University of Campania "Luigi Vanvitelli”, Capua (CE), Italy \\ Correspondence: Filomena Izzo, University of Campania “Luigi Vanvitelli”, Capua (CE), Italy.
}

Received: April 6, 2018

Accepted: April 25, $2018 \quad$ Online Published: May 9, 2018

doi:10.5539/ibr.v11n6p83

URL: https://doi.org/10.5539/ibr.v11n6p83

\begin{abstract}
In the relationship between technologies and museum, a particular attention is to be reserved to the role of immersive technologies in the planning of the museum experience, to the opportunities for the innovation of the museum concept in the development of the visit experience and to the effects that such innovations might have in the enhancement process of museums.

In this article a short examination of the studies on the museum experience is presented, hereafter the results of a case study The Archeologic Museum of Olbia are accounted.
\end{abstract}

Keywords: technologies, museum communication, virtual reality, museum management, museum experience

\section{Introduction}

The museum sector, like other sectors which provide a public service, has been undergoing considerable changes over the latest years. It has been invested by a strong push towards the adoption of management logic aimed at a major effectiveness, efficiency, economic and administrative balance.

In addition to this, there are the complexity of the reference framework, the variability and therefore the speed of changes and the excess of possibility whose it is possible to arrange. Furthermore, the public, here intended as users, spectators, visitors are different in trends, uses, perspectives and wishes.

Technologies marked the way of the development in the modern society, by changing the essence itself of many economic sectors; at the same way even the museum sector is not unresponsive to this innovative wave. (Solima, 2007; Bonacini, 2011, 2014; Solima, Minguzzi, 2012, 2014).

Nowadays, the culture consumption is also based on the interaction between man and the cultural good; under this perspective the correct use of new technologies can bring great advantages to the museums, by helping the fusion of different cultural resources in a unique service which will define the users' experience.

An indirect confirmation of the importance of the circulation of the digital in the museum is given by the result of a recent survey made by the society Axiell on behalf of Museums and the Web's 2016 on the strategies, which are carried out by the main museums in the world in reference to the processes of digitalization. According to Axiell's data, the combined use of informatics applications had relevant impacts on the public: the $48,5 \%$ of the museums registered an increase in the physical visits, the 50\% saw an increase in the visits to the website and the $82,3 \%$ had an increase of the visitors to its social profiles.

To better understand these aspects, it is useful to reflect in a preliminary phase on the museum experience and the application of the experience approach to the management of the cultural property by paying attention to its usefulness to the esteem of the public cultural heritage.

This study pays a close attention to the visit experience in the development of the museum services and the construction of the relation with public people. For this reason, the potentialities of the technology of the virtual reality applied to a case study are presented: Olbia's Archeological Museum.

\section{Theoretic Framework and Method}

\subsection{Literature Review: Museum Experience Studies}

It is a widely shared opinion (Macdonald, Alsford, 1995; Kotler, 1999; Addis, 2002, 2005a, 2005b; McIntyre, 2009; Izzo, 2017a) that museums must be hybrid places able to balance learning and entertainment, by using the 
entertainment only from the perspective of edutainment or in the case it is addressed to an adult public, of the infotainment or as mean of learning and knowledge (Izzo, 2017b).

The studies on the consumption experience in the museums have been following each other since the half of the Nineties, which even different in the approach have the same common denominator: the attention to the visitor (Falk, Dierking, 1992, 2000; Pekarik et al., 1999; Kotler, 1999, 2001; Kotler, Kotler, 2000; Stephen, 2001; Falk, 2009).

Even the consumption experience in the museums highlights a prevailing interest in the emotional (Ferrari, Veltri, 2007, 2008), sensory (Marteaux et al., 2009; Addis, 2011), behavioural and relational (Dierking, 1994; Adams et al., 2004; Falk et al., 2004; Vom Lehn, 2005) aspect of the experience, with a particular concern in the modalities to amaze the public and promote an active participation, by paying few attention to the contents of the communication and the evaluation of their understanding from the public. The risk is of enrupting the visitors, through sensations and feelings which are induced through the promotion of behaviours stretching to the mystic hypnosis (Eco, 1967) instead of favouring the knowledge of the objects displayed at a museum (Giunta, 2011).

The museum studies are focused on the procedures of the innovation of the communication to the public. Besides the studies on the contribution given by the narrative (Kelly, 2010; De Fazio, 2012) techniques, the attention was laid on the possibility of updating the devices of support to the visit (Parry, 2007; Marty, 2008; Tallon, Walker, 2008) to replace the image of the museum based on the prohibitions and the "closed administration" (Dragoni, 2004: 212) with the idea of a museum which favours the active involvement of its users, by diversifying the offer consistently to the needs showed by the different public (Roncaccioli, 1995; Solima, 1998; Moretti, 1999; Montella, 2003; Monaci, 2005).

The literature on the topic is centred on the possibility of offering to the visitor a wide range of choices (Weil, 1997) through the use of the "new technologies" (as matter of fact, these technologies are not new; in fact they are already old, when we consider the new innovation wave: Internet of things, big data, artificial intelligence, additional production, neuro - bio - nanotechnologies are intended not only to change the management and the circulation of information but also the quality of the relation between the digital information, things, objects and places) for the fruition in loco which combines compactness, multimedia, hypertext, flexibility and interactivity (Galluzzi, 1997; Addis, 2002; Witcomb, 2003; Parry, 2007; Marty, 2008; Tallon, Walker, 2008; Bakhshi, Throsby, 2012); furthermore the same ones allow to exploit replicator economies, to contain a high number of different types of information (eg texts, sounds, images) in a limited space to customize the visit experience, by choosing the contents according to the requested level of in-depth analysis to make the visitor individualise the visit and reduce the "cognitive dissonance" and increase the previous knowledge (Breakwell, 1998; Rullani, 2004; Falk, Dierking, 2008; Solima, 2016a, 2016b).

\subsection{Thesis}

In order to make technology represent a real added value, it has not to replace the museum nor be a simple substitute of the guided visit, but it has to be a real mean for the improvement of the communication in loco, which is to be used only where it allows to reach results, otherwise unreachable through the traditional means. Furthermore, the technological instruments must not to be intrusive, meaning that they do not have to interrupt the visit itinerary, to isolate the visitor, to distract him/her from the observation of the displayed items or to impede him/her to interact with other visitors (Deshayes, 2004; Vom Lehn, 2005; Pujol-Tost, Economou, 2007; Jutant et al., 2009).

On the role of the immersion in the consumption processes (Carù, Cova, 2007), in many museums the use of immersive technologies has been affirming itself (Dobrzynsky, 2013; Izzo et al., 2015; Izzo, 2017b). These technologies have bivalent effects which are able to satisfy the cognitive, emotional, recreational and functional experience of the sight (Belaen, 2005), but they cannot always satisfy the social ones; furthermore, their effectiveness depends on the quality of the informational contents which are given to the public (Collin-Lachaud, Passebois, 2008).

\subsection{Methodology}

It is on the immersive technologies that the case, showed in this article, is presented. In particular, it is described the application of the Virtual Reality made by Olbia's Museum.

The app Virtual Reality is an application which can be used through specific devices: stereoscopic head-mounted display with a smartphone to be put inside. This type allows visitors not to overrun the museum area with PCs and several cables, in fact it does not consider an initial setting up nor any cable or an external processing unit. In addition to this, a well experienced staff can help visitors during their fruition. 
The immersive movie of the Virtual Reality involves the visitors at the end of the exhibition, in an area which is devoted to the virtual experience. Through an immersive experience, inspired to the Nuragica experience, the visitor can experience a series of original visual and auditory activities which launch him/her inside the Nuragico world.

The exhibition is the result of a cooperation between the start-up Sardinia Experience (http://www.sardiniaexperience.it/) and the Olbia's Archeological Museum (http://www.olbiaturismo.it/Museo-1.html) .

Sardinia Express is an innovative sturt-up where word as "tourism", "culture", "technology", "emotion" and "system" are based on a new format of entertainment and cultural fruition. The staff is made up by Sardinians who are fascinated by the island, its environment, its culture and history. The deep knowledge of Sardinia is the main background of competencies. The Coperative Sardinia Express is the promoter and the producer of NURAGICA, an engaging and interactive experience able to put in contact the visitors with virtual and commemorative sceneries of the Nuragica period.

The society further than ensure the technological application the Olbia's Archeological Museum, monitored the user's evaluation of the offered service and the performances realised by the museum (eg sold tickets).

In order to evaluate the satisfaction with the technological application, a survey was distributed, whose aim was to examine:

1. The motivation for the use of technological application;

2. The level of satisfaction and the adequacy of the given information;

3. The inclination to repeat the use of an informative system based on the offered technology (Virtual Reality);

4. The general evaluation of the offered service.

The period of the collection of data was that related to the virtual exhibition, from June to November 2017.

\section{Results}

It appeared from the interviews (6000): a good level of general satisfaction; a good judgement on the given information; a high inclination to repeat the experience; the curiosity and desire to have access to further information in order to better understand the displayed works as the main reason which makes the visitors use the application.

The positive data stand out also from the number of visitors; the museum, in particular, before the Nuragica exhibition, counted 6000 visitor per year and the entry was free (there was no ticket to be paid); on the other hand the same numbers were realised in only 5 months of the Nuragica exhibition and the visitors paid also the $10,00 €$ ticket to see it.

Therefore, the studied case confirms what has been already highlighted in literature and by the Axielle data; it is possible to affirm that the experience approach is valid and useful if directed to the creation of cultural public benefits, therefore, starting from this assumption, the technologies used for experiential purposes should keep a function which is instrumental in the cultural and institutional need to communicate the displayed items and not to replace the museum by recurring to show or pure entertainment techniques.

The result of the study show the importance for the museum to offer a more well structured service, which satisfies at the same time the needs of amusement and education (edutainment).

With this aim, the use of a technological application, which is more or less sophisticated to improve the visit experience of the museum can represent one of the main elements of a differentiation strategy. This is fundamental in the current context where the competition between cultural institution and the growing use of alternatives during the free time is developing with an increasing intensity. The museums might increase their competitive advantage compared to their direct rivals by improving the quality of the visit experience. Furthermore, this choice can have a strategic importance in reference to the reputation of the museum itself in order to improve its attractiveness and more generally its ability to relate with its stakeholders.

A more entrepreneurial approach than the one of the past, which allows a fruitful contamination between the cultural sector and the profane one, while unifying experiences which go from the history to the marketing experts and to the multimedia designer. It is an integration of knowledge which becomes crucial to implement a new approach of the cultural heritage management that means: marketing, culture, knowledge, entertainment, personalization and satisfaction. 


\section{Discussion}

The aim of this article is to understand the role of technology as an instrument which contributes to the fulfilment of the museum's goals, by creating value for the survival of the museum institution, its users' satisfaction and the development of the territory.

Placing at the centre of the analysis the core product that is offered by the museums and the process of creation of the value which is connected to it; the research focuses the attention on the changes that technology brings to the nature of the museum institution by transforming it in something new compared to the traditional models in terms of production, fruition and communication and revealing, above all, the new relation that can be set with the users through the immersive technologies.

The study which was carried out shows some limits, the main ones can be referred to the fact that the research activity is, in a scientific sense, a starting point for further studies.

However, it aims at giving the theoretical and empirical requirements for the innovation of the research both in a management field than in a museum marketing, with management implication for the sector workers who intend to employ the analysed devices to optimise the relation with the potential and real users and with its own stakeholders and with the aim of supporting processes of technological innovation in support of the cultural realities of its own country.

\section{Acknowledgments}

Many thanks to Maria Carmela Solinas (Marketing Director of Sardinia Experience) and to Paolo Alberto Pinna (Project Manager of Sardinia Experience) for their precious collaboration.

\section{References}

Adams, M., \& Luke J., Moussouri T. (2004). Interactivity: Moving Beyond Terminology. Curator, 47(2), 155-170. https://doi.org/10.1111/j.2151-6952.2004.tb00115.x

Addis, M. (2005a). L'esperienza di consumo. Analisi e prospettive di marketing. Milano: Pearson Education Italia.

Addis, M. (2002). Nuove tecnologie e consumo di prodotti artistici e culturali: verso l'Edutainment. Micro \& Macro Marketing, XI(1), 33-59.

Addis, M. (2005b). New Technologies and cultural consumption - edutainment is born. European Journal of Marketing, 39(7/8), 729-736. https://doi.org/10.1108/03090560510601734

Addis, M. (2011). Il significato dell'esperienza di consumo nel settore artistico e culturale. In Montella M., \& Cerquetti M., Economia, cultura, territorio (pp. 45-53). Macerata, Italy: EUM.

Bakhshi, H., \& Throsby, D. (2012). New technologies in cultural institutions: theory, evidence and policy implications. International Journal of Cultural Policy, 18(2), 205-222. https://doi.org/10.1080/10286632.2011.587878

Belaen, F. (2005). L'immersion dans les musées de science: médiation ou séduction? Culture \& Musées, 5, 91-110. https://doi.org/10.3406/pumus.2005.1215

Bonacini, E. (2011). Nuove tecnologie per la fruizione e valorizzazione del patrimonio culturale, Roma, Italia: Aracne.

Bonacini, E. (2014). La realtà aumentata e le app culturali in Italia: storie da un matrimonio in mobilità. $I l$ Capitale Culturale, IX, 89-121.

Breakwell, G. (1998). Usage des interactifs au musée. Publics et Musées, 13, 29-40. https://doi.org/10.3406/pumus.1998.1100

Carù, A., \& Cova, B. (2007). Consuming experiences, London: Routledge.

Collin-Lachaud, I., \& Passebois, J. (2008). Do Immersive Technologies Add Value to the Museum going Experience? An Exploratory study conducted at France's Paléosite. International Journal of Arts Management, 11(1), 60-71.

De Fazio, D. (2012). Il museo va in scena. Tecniche teatrali al servizio dei visitatori. Milano, Italia: Franco Angeli.

Deshayes, S. (2004). L'usage des supports mobiles au musée, des audioguides classiques au multimédia nomade. ICHIM - Digital Culture \& Heritagel Patrimoine \& Culture Numérique, Berlin, 31 August - 2 Septembre, 
Archives \& Museum Informatics Europe.

Dierking, L. (1994). Rôle de l'interaction sociale dans l'expérience muséale. Publics et Musées, 5, 19-41. https://doi.org/10.3406/pumus.1994.1035

Dobrzynsky, J. H. (2013). High Culture Goes Hands-On. The New York Times, August 10.

Dragoni, P. (2004). I diversi profili degli addetti ai servizi educativi in relazione al diverso rapporto fra il museo e i suoi utenti. In Iacono, M.R. \& Furia, F., Educazione al patrimonio culturale: problemi di formazione e di metodo. Atti del convegno, Caserta Teatro Reggia, 7-8 ottobre 2002, Arethusa, Roma, Italy.

Eco, U. (1967). Feticci laici nei musei. In Il costume di casa. Evidenze e misteri dell'ideologia italiana negli anni Sessanta (2012, pp. 302-304), Milano, Italy: Bompiani.

Falk, J. H., Scott, C., Dierking, L., Rennie, L., \& Cohen Jones, M. (2004). Interactives and Visitor Learning. Curator, 47(2), 172-198. https://doi.org/10.1111/j.2151-6952.2004.tb00116.x

Falk, J. H. (2009). Identity and Museum Visitor Experience. Walnut Creek, CA: Left Coast Press.

Falk, J. H., \& Dierking, L. D. (1992). The Museum Experience. Washington, D.C.: Whalesback Books.

Falk, J. H., \& Dierking, L. D. (2000). Learning from Museums. Visitors Experiences and the Making of Meaning. Lanham, MD: Altamira Press.

Falk, J. H., \& Dierking, L. D. (2008). Enhancing Visitor Interaction and Learning with Mobile Technologies. In (eds.) Tallon, L., \& Walker, K., Digital technologies and the museum experience: Handheld guides and Other Media (pp. 19-34). Lanham, MD: Altamira Press.

Ferrari, S., \& Veltri, A. R. (2007). L'approccio esperienziale nell'offerta dei beni culturali. Il caso di "Emozioni da museo". Finanza, Marketing e Produzione, 4, 66-95.

Ferrari, S., \& Veltri, A. R. (2008). L'approccio esperienziale ai beni culturali come strumento di differenziazione dell'offerta turistica, http: //www.fizz.it/home/sites/default/files/ allegati/articoli/pdf_articoli_completi/2007-ferrari_veltri.pdf

Galluzzi, P. (1997). Nuove tecnologie e funzione culturale dei musei. Opportunità e scenari per il terzo millennio. In Galluzzi, P., Valentino, P.A., I formati della memoria. Beni culturali e nuove tecnologie alle soglie del terzo millennio (pp. 3-39). Firenze, Italy: Giunti.

Giunta, C. (2011). Come si diventa "Michelangelo". Il mercato dell'arte, la retorica, l'Italia. Roma, Italy: Donzelli.

Izzo, F., Mustilli, M., \& Guida, M. (2015). Realtà aumentata e valorizzazione dei beni culturali. Riflessioni sull'offerta culturale casertana (797-809). Conference proceeding, Sinergie Annual Conference, Termoli, Italy.

Izzo, F. (2017a). Implementation of Augmented Reality in Real Palace Museum of Naples: an organizational perspective. Conference proceeding, WOSH Conference, Roma, Italy.

Izzo, F. (2017b). Museum Customer Experience and Virtual Reality: H. Bosch Exhibition Case Study. Modern Economy, 8, 531-536.

Jutant, C., Guyot, A, \& Gentès, A. (2009). Visiteur ou joule? Les multiples facettes de la technologie RFID. La Lettre de l'OCIM, 125, 12-20.

Kelly, L. (2010). Engaging Museum Visitors in Difficult Topics Through Socio-Cultural Learning and Narrative. In (eds.) Cameron, F., Kelly, L., Hot Topics, Public Culture, Museum (pp. 194-210). Newcastle upon Tyne: Cambridge Scholars Publishing.

Kotler, N. (1999). Delivering Experiences: Marketing the Museum's Full Range of Assets. Museum news, May/June.

Kotler, N. (2001). New Ways of Experiencing Culture: The Role of Museums and Marketing Implications. Museum Management and Curatorship, 19(4), 417-425. https://doi.org/10.1080/09647770100801904

Kotler, N., \& Kotler, P. (2000). Can Museums Be All Things to All People? Missions, Goals, and Marketing's Role. Museum Management and Curatorship, 18(3), 271-287. https://doi.org/10.1080/09647770000301803

Macdonald, G. F., \& Alsford, S. (1995). Museums and Theme Parks: World in Collision? Museum Management and Curatorship, 14(2), 129-147. https://doi.org/10.1080/09647779509515435

Marteaux, S., Mencarelli, R., \& Pulh, M. (2009). Quand les institutions culturelles s'ouvrent au marketing 
sensorial... et s'en défendent: enjeux et paradoxes. Management \& Avenir, 22(2), 92-108.

Marty, P. F. (2008). Interactive Technologies. In (eds.) Marty, P.F., Burton, \& Jones, K., Museum Informatics. People, Information, and Technology in Museums, 131-135. London-New York: Routledge.

McIntyre, C. (2009). Museum and Art Gallery Experience Space Characteristics: an Entertaining Show or a Contemplative Bathe? International Journal of Tourism Research, 11, 155-170. https://doi.org/10.1002/jtr.717

Monaci, S. (2005). Il futuro nel museo. Come i nuovi media cambiano l'esperienza del pubblico. Milano, Italy: Guerini e Associati.

Montella, M. (2003). Musei e beni culturali. Verso un modello di governance. Milano, Italy: Mondadori Electa.

Moretti, A. (1999). Un'organizzazione museale multiunit: i Musei Civici di Venezia. In (ed) Zan, L., Conservazione e innovazione nei musei italiani: management e processi di cambiamento, Milano, Italy: Etas.

Parry, R. (2007). Recoding the Museum. Digital Heritage and the Technologies of Change. London-New York: Routledge. https://doi.org/10.4324/9780203347485

Pekarik, A. J., Doering, Z. D., \& Karns, D. A. (1999). Exploring Satisfying Experiences in museums. Curator, 42(2), 152-173. https://doi.org/10.1111/j.2151-6952.1999.tb01137.x

Pujol-Tost, \& L., Economou M. (2007). Exploring the suitability of Virtual Reality interactivity for exhibitions through and integrated evaluation: the case of the Ename Museum. Museology e-journal, 4, 81-97.

Roncaccioli, A. (1995). L'azienda museo: problemi economici, gestionali e organizzativi. Padova, Italy: CEDAM.

Rullani, E. (2004). La fabbrica dell'immateriale. Produrre valore con la conoscenza. Roma, Italy: Carocci.

Solima, L. (1998). La gestione imprenditoriale dei musei. Percorsi strategici e competitivi nel settore dei beni culturali. Padova, Italy: CEDAM.

Solima, L. (2007). Nuove tecnologie della comunicazione. Economia della Cultura, 3, 365-375.

Solima, L. (2016a). Smart Museums. Sul prossimo avvento della Internet of Things e del dialogo tra gli oggetti nei luoghi della cultura. Sinergie, n. 99, 263-283.

Solima, L. (2016b). Ricostruire l'antico, Museo Archeologico Nazionale di Napoli Workshop, Naples, Italy.

Solima, L., \& Minguzzi, A. (2012). Relazioni virtuose tra patrimonio culturale, turismo e industrie creative a supporto dei processi di sviluppo territoriale. XXIV Sinergie Annual Conference, Territorio come Giacimento di Vitalità per l'Impresa", 18-19 october.

Solima L., \& Minguzzi, A. (2014). Territorial development through cultural tourism and creative activities. Mondes du Tourism, 10, December, 6-18. https://doi.org/10.4000/tourisme.366

Stephen, A. (2001). The Contemporary Museum and Leisure: Recreation as a Museum Function. Museum Management and Curatorship, 19(3), 297-308. https://doi.org/10.1080/09647770100601903

Tallon, L., \& Walker, K. (2008). Digital Technologies and the museum experience: Handheld Guides and Other Media. Lanham, MD: Altamira Press.

Vom Lehn, D. (2005). Embodying experience: A video-based examination of visitors' conduct and interaction in

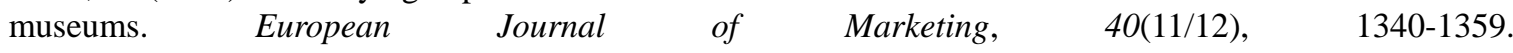
https://doi.org/10.1108/03090560610702849

Weil, S. E. (1997). The Museum and the Public. Museum Management and Curatorship, 16(3), 257-271. https://doi.org/10.1080/09647779708565852

Witcomb, A. (2003). Re-Imaging the Museum. Beyond the Mausoleum. London-New York: Routledge.

\section{Copyrights}

Copyright for this article is retained by the author(s), with first publication rights granted to the journal.

This is an open-access article distributed under the terms and conditions of the Creative Commons Attribution license (http://creativecommons.org/licenses/by/4.0/). 